\title{
REFLEXIONES EPISTEMOLÓGICAS Y ONTOLÓGICAS SOBRE LOS VIRUS: HACIA UNA NUEVA DEFINICIÓN DE LOS PROCESOS VIRALES
}

\author{
EPISTEMOLOGICAL AND ONTOLOGICAL REFLECTIONS \\ ON VIRUSES: \\ TOWARDS A NEW DEFINITION OF VIRAL PROCESSES
}

\begin{abstract}
Joaquín Vidal López ${ }^{a^{*}}$
\end{abstract}
Fechas de recepción y aceptación: 14 de junio de 2020 y 25 de junio de 2020

DOI: $10.46583 /$ scio_2020.19.609

Resumen: El estudio de los virus ha experimentado una gran transformación en las primeras décadas del siglo XXI. El descubrimiento de los virus gigantes ha hecho que la distinción entre algunos tipos de virus y de bacterias sea cada vez más difusa, lo que obliga a replantearse el estatus epistemológico y ontológico de estas entidades biológicas. Tanto la visión clásica de los virus por parte de la biología, como las definiciones generales que utilizan las autoridades sanitarias y las definiciones realizadas por virólogos y microbiólogos necesitan ser revisadas para dar cabida a los conocimientos actuales sobre los virus, o más concretamente, sobre los procesos virales. En este proceso de nuevos descubrimientos aparecen nuevos términos, como virión, viroide, virobiota, viroma y virocélula, que deben ser tenidos en cuenta e integrados en un nuevo marco ontológico y epistemológico general. Aunque aún estamos lejos de conseguir una definición generalmente aceptada que permita diferenciar nítidamente a los virus de otras entidades biológicas

\footnotetext{
a Director de la School of Advanced Education, Research and Accreditation (SAERA). Grupo de Investigación "Emoción, Cognición, Acción" de la Universidad Católica de Valencia San Vicente Mártir.

${ }^{*}$ Correspondencia: Escuela de Formación Superior (SAERA). Calle Germanías, 3. 1. ${ }^{\circ}$ C. 12001. Castellón de la Plana. España.

E-mail: joaquinvidal.ps@gmail.com
} 
similares, al final del artículo se presenta una definición tentativa, que trata de evitar las limitaciones que presentaban las definiciones anteriores.

Palabras clave: virus, proceso viral, virión, virocélula, viroide, epistemología, ontología.

Summary: The study of viruses has undergone a great transformation in the first decades of the $21^{\text {st }}$ century. The discovery of giant viruses has made the distinction between some types of viruses and bacteria increasingly blurred, forcing us to rethink the epistemological and ontological status of these biological entities. Both the classic view of viruses in biology and the general definitions that health authorities make of these entities, as well as the definitions made by virologists and microbiologists needed to be revised to fit the current knowledge about the viral processes. New terms appear in this process of discoveries, such as virion, viroid, virobiota, virome and virocell which must be taken into account and integrated into a new general ontological and epistemological framework. Although we are still far from achieving a generally accepted definition that allows viruses to be clearly differentiated from other similar biological entities, a tentative definition is presented at the end of the paper, which tries to avoid the limitations presented by the previous definitions.

Keywords: virus, viral process, virion, virocell, viroid, epistemology, ontology.

\section{$\S 1$ INTRODUCCIÓN}

La biología clásica considera los virus como unos "trozos desprendidos de información genética" (Curtis y Barnes, 1993). Según este punto de vista, los virus son unos organismos a mitad de camino entre los seres animados y los inanimados, que son difíciles de clasificar en ninguno de los reinos de seres vivientes.

Esto hace de los virus un tema interesante de estudio por parte de la filosofía, de la biología y de todas las ciencias de la vida en general.

Entre las enfermedades humanas causadas por los virus no solamente tenemos la COVID-19, sino que los virus también son los responsables de las 
gripes, el sarampión, la rabia y numerosas infecciones de la piel, de las mucosas o de las vías respiratorias.

El premio nobel de fisiología o medicina en 1969, Salvador Edward Luria, escribió, junto con James E. Darnell, el primer libro dedicado en exclusiva a los virus (Virología General). En este tratado, los autores consideraban los virus como "trozos de herencia en busca de un cromosoma" (Luria y Darnell, 1977).

\subsection{Aspectos generales de los virus}

La mayoría de los virus están formados por un ácido nucleico ${ }^{1}$, que puede ser de ADN o de ARN, envuelto en una cubierta de proteínas que puede adoptar formas diversas (Curtis y Barnes, 1993). Es esta cubierta la que determina a qué células es capaz de atacar el virus, porque este solamente puede infectar a una célula si esta posee un receptor compatible con la proteína viral.

Por otro lado, los virus solamente se pueden multiplicar dentro de las células vivas. En algunas infecciones, la cubierta de proteínas se queda fuera de la célula, y únicamente entra el ácido nucleico en el interior de esta. Sin embargo, en otras, entra el virus entero y, una vez dentro de la célula, la proteína se destruye por las enzimas del citoplasma de esta y el ácido nucleico se libera.

En los virus de ADN, el ADN viral también se replica como ARN mensajero $^{2}$, de esta manera puede sintetizar las proteínas y enzimas que el virus necesita para formar las nuevas cubiertas de proteínas. Los virus realizan

${ }^{1}$ Los ácidos nucleicos son un tipo de moléculas de gran tamaño que se encuentran en todas las células y virus. Estas macromoléculas se encargan de almacenar y de expresar la información genética. Los dos tipos principales de ácidos nucleicos son: $a$ ) el ácido desoxirribonucleico (ADN) que codifica (almacena) la información que las células necesitan para sintetizar las proteínas mediante una doble cadena de nucleótidos (aunque en algunos virus, el ADN es monocatenario), y b) el ácido ribonucleico (ARN), que participa también en la síntesis de proteínas, es siempre monocatenario, aunque en ciertas circunstancias se pueden formar estructuras plegadas complejas. Como norma general para el funcionamiento de las células, el ADN almacena la información, mientras que el ARN la expresa.

${ }^{2}$ El ARN mensajero es el ácido ribonucleico que se encarga de transferir la secuencia del ADN a un orgánulo del citoplasma de las células, llamado ribosoma, que se encarga de sintetizar proteínas siguiendo el código genético.

SCIO. Revista de Filosofí, n. ${ }^{\circ}$ 19, Noviembre de 2020, 183-208, ISSN: 1887-9853

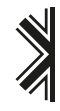


todas las labores de síntesis utilizando las distintas partes de la célula que ha infectado.

En los virus de ARN, el ácido nucleico se replica y sirve directamente como ARN mensajero.

Lo que finalmente consiguen ambos tipos de virus con la infección es la producción de cientos o miles de nuevas copias de virus.

Todas estas nuevas copias se forman dentro de la célula infectada. Esta a menudo se rompe para liberar las nuevas copias de virus (Curtis y Barnes, 1993).

\subsection{Algunos descubrimientos recientes sobre los virus}

Más allá de esta visión clásica de los virus, la ciencia moderna ha realizado en los últimos años importantes avances sobre el conocimiento que tenemos de estas entidades biológicas. Esto ha hecho que nos debamos plantear ciertas cuestiones filosóficas y científicas sobre los virus, que hasta hace unos años no podíamos ni imaginar.

En los apartados siguientes de este artículo abordaremos algunas de estas cuestiones. Pero veamos antes algunos ejemplos.

Los virus son, con diferencia, los organismos más abundantes sobre la tierra. Se ha encontrado una gran cantidad de partículas virales en numerosas muestras ambientales y se ha visto que los virus representan el mayor reservorio de nueva diversidad genética del planeta (Forterre, 2013).

Estas cadenas de información genética codificada, que son los virus, están infectando continuamente los microbios de los océanos. El proceso de replicación constante de virus hace que se destruyan miles de millones de bacterias cada segundo. De hecho, los virus matan a la mitad de todas las bacterias de todos los océanos del mundo cada día. Esto representa una cantidad inmensa de carbono que se está liberando constantemente a los océanos y a la atmósfera desde el interior de estas bacterias (Zimmer, 2015).

Se sabe que una parte de este carbono va a parar al suelo del océano, otra parte sirve para fertilizar el nacimiento de nuevas bacterias en la superficie 
marina, y otra parte puede, en parte, influir en los cambios climáticos. Todavía no conocemos completamente estos efectos, pero pueden llegar a ser importantes (Zimmer, 2015).

Los virus, por lo tanto, tienen algo de desconcertante para los científicos. Se hallan a mitad de camino entre los seres vivos y los objetos inertes. Constituyen el organismo más abundante en la Tierra y parecen ser un poderoso motor de cambio biológico.

\section{§2. DEFINICIÓN GENERAL DE VIRUS}

En este apartado vamos a comentar cómo se suelen definir los virus, cuando las definiciones van orientadas para el público en general, y qué problemas presentan estas diferentes definiciones.

Para reflexionar sobre las definiciones generales de virus, tomaremos como punto de partida la explicación ofrecida por el National Human Genome Research Institute, organismo dependiente del National Institute of Health de Estados Unidos ${ }^{3}$.

Según esta institución:

Un virus es un agente infeccioso que está en el límite de lo que consideramos un organismo vivo. Es una partícula mucho más pequeña que una célula bacteriana, y consiste en un pequeño genoma de ADN o ARN rodeado por una cubierta proteica. Los virus entran en las células huésped y secuestran las enzimas y los materiales de dichas células huésped para producir más copias de sí mismos. Los virus causan una amplia variedad

\footnotetext{
${ }^{3}$ Hemos elegido esta definición por ser una de las comúnmente aceptadas a nivel mundial. Otras definiciones semejantes ofrecidas en España presentan las mismas limitaciones. Por ejemplo, en la página Ciencia en Canarias, dependiente del Gobierno de Canarias, se define a los virus como "una molécula genética relativamente pequeña [...]. Una vez alcanzan el núcleo, donde reside el grueso de la maquinaria celular, lo secuestran para su propio beneficio" (Ciencia Canaria - Gobierno de Canarias, 2020), que enfatiza la naturaleza "egoísta" de los virus. Mientras que la definición de la Real Academia Española (virus es "un organismo de estructura muy sencilla, compuesto de proteínas y ácidos nucleicos, y capaz de reproducirse solo en el seno de células vivas específicas, utilizando su metabolismo") enfatiza el carácter "externo" del virus a la célula (Real Academia Española, 2020).
} 
de enfermedades en plantas, hongos y animales, incluido el SIDA, el sarampión, la viruela y la poliomielitis (National Human Genome Research Institute, 2020).

\subsection{Primer problema con la definición: ¿son los virus agentes infecciosos y causantes de enfermedades?}

Es cierto que la mayoría de definiciones, como la que acabamos de presentar, describen los virus como agentes infecciosos. No es extrañar que esto suceda, dado los millones de muertes que los virus provocan en los seres humanos cada año.

Hay virus incluso que son capaces de reducir la fertilidad o modificar la conducta de los seres vivos infectados por ellos. Pero debemos tener en cuenta que no solamente los virus provocan infecciones y enfermedades graves. Esta característica dañina se da también en otros muchos organismos y sustancias de la naturaleza. Pero ¿son siempre dañinos los virus?

La gran mayoría de virus son neutros o incluso beneficiosos para sus huéspedes. Por ejemplo, muchas bacterias de los océanos y mares de todo el planeta adquieren la capacidad para realizar la fotosíntesis tras ser infectadas por virus (Lindell, Jaffe, Johnson, Church y Chisholm, 2005).

Los virus en realidad son entidades mutualistas, como sucede con la mayoría de seres vivos cuando entran en contacto con otras especies. De manera que, dependiendo de las condiciones espacio-temporales en las que se produzca el contacto, se pueden provocar efectos más o menos dañinos o beneficiosos entre ellas. En ocasiones, los encuentros serán letales o dañinos, en otras aumentarán el bienestar del individuo, y habrá incluso interacciones en los que los virus sean indispensables para el desarrollo del huésped, para su supervivencia o para su reproducción (Pradeu, 2016).

En las relaciones mutualistas, los virus benefician la mayor parte del tiempo a los individuos de un determinado nicho ecológico, en el cual ellos y los huéspedes pueden vivir y reproducirse de manera eficiente. ¿Cómo se puede ver beneficiado el huésped? Veamos algunos ejemplos. 


\subsection{Beneficios de los virus para el desarrollo de los huéspedes}

Siguiendo a Pradeu (2016), el desarrollo normal del ciclo vital de algunos organismos necesita de la presencia de virus para poder producirse.

Por ejemplo, las avispas parasitoides paralizan a sus víctimas (diferentes tipos de insectos) e introducen sus huevos dentro de ellas para poder reproducirse. Para defenderse, el sistema inmunitario de los insectos infectados a menudo encapsula los huevos de la avispa y de esta manera consiguen neutralizarlos. Pero unos tipos de virus (los polidnavirus ${ }^{4}$ ) suprimen la respuesta inmune de los insectos y los huevos de la avispa parasitoide consiguen sobrevivir.

No se trata de un caso aislado, sino que este efecto se da con mucha frecuencia en la naturaleza. Se cree que hay unas 30.000 especies de avispas que tienen su virus específico para ayudar en su reproducción (Webb et al., 2006).

La evolución de las placentas en los mamíferos, incluidos los humanos, es posible gracias a la acción de los retrovirus endógenos ${ }^{5}$ (Mallet et al., 2004). Para que las membranas celulares de la madre se puedan fusionar, y así empezar a desarrollarse la placenta, es imprescindible la acción de este tipo de virus.

Volvemos a ver otro caso, en el que la presencia de un virus asociado a la especie es necesaria para el normal desarrollo de los individuos de esa especie.

Por último, se sabe desde hace tiempo que los ratones que son criados sin ningún tipo de germen desarrollan malformaciones en el intestino y problemas en el funcionamiento de los linfocitos. Las bacterias intestinales, por tanto, son imprescindibles para el buen funcionamiento del aparato digestivo. Pues bien, unos investigadores (Kernbauer, Ding y Cadwell, 2014) han demostrado que la infección de estos ratones libres de gérmenes con el norovirus murino $^{6}$ repara la morfología del intestino y mejora la inmunidad de la mucosa intestinal, sin que se produzcan grandes inflamaciones ni otras enfermedades.

\footnotetext{
${ }^{4}$ Los polidnavirus son un tipo de virus que infecta a los insectos, cuyo genoma está compuesto por ADN bicatenario recubierto por una envoltura y una cápside de proteínas.

${ }^{5}$ Los retrovirus endógenos son elementos virales que forman parte del genoma de un vertebrado, pero cuya secuencia de ADN proviene de un virus.

${ }^{6}$ El norovirus murino es un tipo de virus que afecta a los ratones, y sirve de modelo experimental para el norovirus humano, que provoca en los individuos infectados dolor estomacal, vómitos y diarrea sin sangrado.
} 
Estos y otros muchos hallazgos han llevado a algunos autores a hablar de la virobiota (estudio de todos los virus que habitan en un huésped) y el viroma (todo el conjunto de genes de una virobiota), que podrían llegar a ser cruciales para el normal desarrollo y salud de la mayoría de los seres vivos (Pradeu, 2016).

\subsection{Protección del huésped}

Los pararetrovirus ${ }^{7}$ protegen a las plantas que lo poseen de otros virus que resultan mucho más patógenos. En los mamíferos, la presencia de determinados virus también protege de diferentes infecciones que pueden ser provocadas por otros agentes patógenos (virus o bacterias).

En los humanos, por ejemplo, el virus del SIDA se desarrolla más lentamente si el individuo está infectado previamente por el virus de la hepatitis G, mucho más común que el anterior y considerado un virus no patógeno.

Hay otros muchos más ejemplos, como el de los herpes virus latentes, que previenen las infecciones bacterianas, o los virus linfotróficos, que previenen la diabetes tipo I (Pradeu, 2016).

Por lo dicho hasta ahora, no es un rasgo mayoritario, distintivo, ni exclusivo de los virus el hecho de ser agentes infecciosos, ni el de provocar enfermedades. Los virus interaccionan de maneras mucho más variadas con los demás seres vivos, de forma similar a como lo hacen las bacterias y los hongos.

\subsection{Segundo problema con la definición: ¿Son los virus mucho más pequeños que las bacterias?}

Tradicionalmente se creía que era así. El primer estudio médico de los virus desde la ciencia moderna fue llevado a cabo por Louis Pasteur. Este químico y bacteriólogo francés descubrió, al estudiar el virus de la rabia, que

\footnotetext{
${ }^{7}$ Los pararetrovirus, o virus ADN retrotranscritos, son virus compuestos por una cadena de ADN bicatenario que infectan a las plantas.
} 
era incapaz de ver el agente infeccioso con el microscopio óptico, ni de filtrarlo con los sistemas que habitualmente se usaban para conseguir muestras de bacterias, por lo que postuló la teoría de que había enfermedades que estaban causadas por "pequeños agentes infecciosos" que crecen en el interior de las personas contagiadas y son capaces de pasarse a otras personas, causándoles enfermedad (Smith, 2012).

Aunque en algunos aspectos Pasteur llevaba razón, en esta definición se deberían incluir también otras muchas bacterias, y hongos de pequeño tamaño que entrarían dentro de esta clasificación.

Hoy en día, sabemos que no es cierto que los virus sean más pequeños que las bacterias. En muchos casos es así, pero existe una enorme diversidad de virus gigantes ${ }^{8}$, que superan en tamaño a muchas bacterias y que se pueden agrupar en siete familias dentro de la taxonomía de virus (ICTV: International Committe on the Taxonomy of Viruses), que comentaremos más adelante en este artículo.

\subsection{Tercer problema con la definición: ¿Tienen siempre los virus una cubierta proteica?}

El término cubierta proteica resulta ambiguo, y en todos los virus habría que distinguir entre:

- La envoltura vírica: es una estructura de proteínas que rodea la cápside vírica. La envoltura vírica es mucho más frecuente en los virus animales que en los que infectan a las plantas o a las bacterias, aunque algunos virus no poseen esta envoltura.

- La cápside vírica: es una estructura de proteínas que rodea el material genético del virus.

${ }^{8}$ Los virus gigantes, también llamados virus nucleocitoplasmáticos de ADN de gran tamaño, son tan grandes, o en ocasiones mayores, como las bacterias pequeñas, tanto en diámetro, como en longitud de su ADN. Muchos de ellos son infectados por otros virus (llamados virófagos). Poseen pocos genes en común con el resto de virus, y dichos genes tampoco son propios de las células. 
- El material genético: constituyen las cadenas de ADN y de ARN que contienen la información genética del virus.

Por lo tanto, los virus suelen tener algún tipo de proteínas que protege el material genético y facilitan el acoplamiento a la membrana de la célula huésped.

Un caso especial es el de los viroides, en los que las cadenas de material genético (en este caso ARN) no disponen de cápside vírica y estas cadenas de ARN mantienen su capacidad para infectar únicamente a las células vegetales.

\subsection{Otros problemas de la mayoría de definiciones de virus}

La mayoría de definiciones de virus utilizan conceptos definidos de manera negativa. Así, los virus son explicados como entidades que carecen de metabolismo, o de capacidad de replicación por sí mismos (sin ayuda de las bacterias o células que los hospedan). Sin embargo, los virus, como cualquier otro concepto que queramos estudiar, deberían poder ser definidos por lo que son o lo que poseen, no por lo que carecen (Pradeau, Kostyrka y Dupré, 2016).

También es frecuente encontrar definiciones en las que se enfatiza la falta de autonomía de los virus. Por ejemplo, muchas definiciones explican que los virus son parásitos o entidades intercelulares con una gran dependencia del huésped. Sin embargo, la simbiosis y la dependencia mutua de los organismos se dan de manera generalizada en toda la naturaleza y no se trata de una característica única de los virus (Pradeau, Kostyrka y Dupré, 2016).

Hay virus que muestran un comportamiento relativamente autónomo, como los mimivirus ${ }^{9}$, que son capaces de generar sus propias cadenas de pro-

\footnotetext{
${ }^{9}$ Los mimivurus son un tipo de virus de gran tamaño (entre 400 y $500 \mathrm{~nm}$ de diámetro, incluyendo la cápside vírica) y que constan de un $\mathrm{ADN}$ de doble cadena. Cuando fueron descubiertos por primera vez en 1992, en una torre de refrigeración industrial, se encontraron dentro de una ameba (Acanthamoeba polyphaga), y fueron confundidos con una bacteria por su gran tamaño y porque teñía la tinción Gram (que se utiliza para ver mejor a las bacterias al analizar muestras clínicas). En concreto, este virus resultaba teñido con el colorante como si fuera una bacteria Gram positiva. Se le denominó "mimivirus" por la supuesta capacidad de mimetización con las bacterias.
} 
teínas, por lo que muestran un comportamiento mucho más autónomo que el de muchas células que deben vivir como totalmente parásitas de otros seres vivos, o las células de un organismo complejo, como los vertebrados, que deben vivir formando parte de un organismo mayor.

En definitiva, los diferentes tipos de seres vivientes muestran diferentes grados de autonomía. Por lo tanto, no es una característica definitoria ni distintiva de los virus su falta de autonomía.

\subsection{Conclusión}

Por lo que hemos visto hasta ahora, resulta complicado llegar a una definición de virus distintiva y precisa, dado que no todos los virus son dañinos, ni son totalmente dependientes, ni deberían ser definidos por lo que carecen.

Para llegar a una definición, también sería interesante conocer hasta qué punto los virus poseen cierto grado de individualidad y de identidad a lo largo del tiempo. Esto es algo que veremos en el siguiente apartado.

\section{§3. ¿DÓNDE Y CUÁNDO EMPIEZA Y TERMINA UN VIRUS?}

Los virus no forman una identidad estática sino que, como el resto de organismos vivientes, cambian de manera significativa a lo largo del tiempo.

Un aspecto que habría que determinar es si los virus son una partícula viral, llamada virión ${ }^{10}$, o si incluyen todo el ciclo viral.

Los virus cambian drásticamente de forma a lo largo del ciclo de replicación viral. En este ciclo se dan las siguientes fases ${ }^{11}$ :

${ }^{10}$ El virión es la partícula vírica capaz de causar infección que consta de todas sus partes (cápside, y genoma siempre, y envoltura vírica los que la posean). Es la forma que adopta el virus cuando se encuentra fuera de la célula huésped, una vez que ha sido liberado, y antes de que proceda a la siguiente infección.

${ }^{11}$ Describiremos un modelo de replicación viral estándar, en el que se podrán producir modificaciones en cada tipo de virus concreto.

SCIO. Revista de Filosofia, n. ${ }^{\circ}$ 19, Noviembre de 2020, 183-208, ISSN: 1887-9853 
1. Adherencia del virus (virión) a la membrana celular.

2. Entrada del virus en la célula huésped.

3. Pérdida de la capa de proteínas que recubre y protege al virus.

4. Síntesis de los nuevos virus, que incluye la replicación de la cadena de nucleótidos y la creación de nuevas capas de proteínas.

5. Unión o ensamblaje de las cadenas de nucleótidos con las capas de proteínas.

6. Liberación de los nuevos virus (viriones) al espacio extracelular.

El ciclo viral parece ser lo que mejor describe al virus en su conjunto que, como cualquier entidad biológica, pasa por varios estadios de desarrollo.

Sin embargo, a menudo, los virólogos se refieren a la cadena de nucleótidos o al virión para referirse al virus.

Así, de manera frecuente se incluye en las definiciones de virus la característica de que las células eucariotas contienen cadenas de ARN y de ADN, mientras que los virus solamente contienen una de ellas (ver la definición clásica que aparecía en el punto 1 de este artículo).

También es frecuente, al referirse a la reproducción de otros organismos, hablar de todos sus constituyentes (cuando se reproduce un ser humano, o un caballo, o una célula, por ejemplo, no decimos que replica su ADN, sino que nos referimos a todo lo que constituye ese organismo).

Sin embargo, al hablar de los virus se suele hacer referencia a que se reproduce la cadena de nucleótidos. Sin embargo, el virus está presente (y se comporta como virus) en todas las fases del ciclo de replicación viral.

\subsection{Los virus como proceso}

Algunos autores (Dupré, 2012) han propuesto que los virus serían más un "proceso" que una "cosa" o "sustancia" y, de hecho, en el campo de la biología el cambio es mucho más frecuente que la estabilidad. 
Entender los virus como un proceso podría ayudarnos a reconsiderar la naturaleza ontológica de otras muchas entidades biológicas. Esto abre la puerta a que puedan ser considerados también como procesos las plantas, los hongos o las comunidades de organismos en simbiosis.

\section{2 ¿Hay diferentes especies de virus?}

La creación de taxonomías de microbios resulta complicada dada la naturaleza cambiante de estos microorganismos y la amplia variedad que se puede encontrar en la naturaleza. Esta tarea resulta incluso más complicada en el estudio de los virus.

Desde los años setenta del siglo pasado se han realizado diferentes intentos por crear taxonomías de los virus basadas tanto en sus características estructurales como en su desarrollo filogenético. La página web del International Committe on the Taxonomy of Viruses ${ }^{12}$ recoge estas clasificaciones.

Sin embargo, en los virus son frecuentes las transferencias de material genético entre unos tipos de virus y otros. También son frecuentes las incorporaciones de material genético de las células huésped en las nuevas copias de virus.

Esto hace muy difícil el establecimiento de una estructura taxonómica de virus en forma de árbol genealógico, como la que se da en los organismos pluricelulares. Por eso, algunos autores han propuesto que sería más acertado hablar de una retícula de tipos de virus, que incluyera la pluralidad que se da dentro de estas entidades biológicas.

Uno de estos autores es Gregory J. Morgan, defensor de la teoría del pluralismo radical, según la cual algunos virus pueden ser miembros de varias especies a la vez (dada su naturaleza cambiante y su extremada adaptabilidad), mientras que otros no podrían clasificarse en ninguna especie concreta,

${ }^{12} \mathrm{El}$ International Committe on the Taxonomy of Viruses (https://talk.ictvonline.org) es una institución dependiente de la Unión Internacional de Sociedades Microbiológicas, cuya función es desarrollar, mejorar y mantener una taxonomía universal de virus. Esta tarea resulta especialmente complicada con los virus por su naturaleza cambiante, y por ello hay autores, como los que comentamos en este trabajo, que se muestran críticos con esta clasificación.

SCIO. Revista de Filosofía, n. ${ }^{\circ}$ 19, Noviembre de 2020, 183-208, ISSN: 1887-9853 
sino que deberían ser clasificados como unas retículas que incluyen diferentes posibles categorías (Morgan, 2016).

En el siguiente apartado veremos si se pueden considerar a los virus como seres vivos.

\section{§4. ¿ESTÁN VIVOS LOS VIRUS?}

Para responder a esta pregunta, lo primero que nos deberíamos plantear es qué se entiende por vida, pero responder a esta pregunta es tremendamente difícil y deberíamos dedicar otro trabajo para este cometido.

Sin embargo, si tomamos una definición estándar de vida, según la cual esta sería una propiedad de algunas entidades biológicas que evolucionan, se adaptan al medio, se desarrollan y se reproducen, los virus podrían encajar parcialmente en esta categoría.

En las últimas décadas se han realizado nuevos descubrimientos sobre la existencia de los virus gigantes. Se trata de virus de un tamaño tal que pueden ser vistos con el microscopio óptico. Estos virus también cuentan con un gran genoma compuesto de una doble cadena de ADN y con una gran cantidad de genes (La Scola et al., 2008).

Esto nos lleva a cambiar nuestro punto de vista sobre si los virus son seres vivos o no. Resulta muy difícil establecer un límite claro entre algunos organismos celulares que dependen por completo de sus huéspedes y que alojan una cantidad pequeña de genes, y los virus gigantes que codifican una cantidad relativamente alta de genes, tienen cierta autonomía y pueden haber sido decisivos en el origen de la vida (Pradeau, Kostyrka y Dupré, 2016).

Sin embargo, la definición de ser vivo en ocasiones no encaja bien con los virus. Cuando se parte de definiciones de vida que se centran sobre todo en la capacidad del organismo para llevar a cabo procesos metabólicos de manera autónoma, se suele excluir a los virus de esta categoría de ser vivo.

Por el contrario, en las definiciones de vida en que se enfatiza la característica de ser un proceso evolutivo, se suele incluir a los virus dentro del conjunto de seres vivos (Pradeau, Kostyrka y Dupré, 2016). 
Podríamos decir que, en general, hay más elementos a favor de considerar a los virus como seres vivos que en contra. En concreto, los virus:

- Son entidades que siguen los principios de la evolución de Darwin: pueden replicarse, y están sometidos a procesos de cambio y evolución. También ejercen una presión evolutiva sobre sus huéspedes.

- Ejercen una función destacada en numerosos ecosistemas, como por ejemplo en los ecosistemas marinos.

Incluso más importante que la cuestión de si los virus están vivos o no es el hecho de considerar qué hacen los virus por la vida en la Tierra.

La respuesta es que los virus son unos actores ecológicos destacados (O’Malley, 2016), porque participan en las redes de comida más importantes del planeta y, además, provocan cambios en la bioquímica de la Tierra, porque controlan los ciclos de carbono, nitrógeno y fósforo.

O’Malley (2016) considera que son unos actores ecológicos al menos tan importantes o más que el resto de organismos actuantes sobre la ecología del planeta.

Por último, como hemos visto en el apartado anterior, los virus se podrían entender más como procesos que como sustancias o individuos independientes.

Si esto es así, la unidad de vida podría ser considerada la virocélula (es decir, la célula infectada que está hospedando a un virus), y de esta manera, sería mucho más sencillo considerar a los virus (virocélulas, en este caso) como entidades vivas (Forterre, 2016). Para este autor, la virocélula sería la "forma de vida" del virus, mientras que los viriones serían como las semillas de una planta (o las esporas de una bacteria) que están esperando su momento para germinar (Forterre, 2013).

Tampoco sería adecuado, para este autor, contar el número de viriones que hay en un lugar determinado para contar el número de virus, como no lo es contar el número de huevas para decir cuántos peces hay.

Por término medio, en cualquier muestra de bacterias, un $40 \%$ de ellas se halla infectada por virus y son, por tanto, virocélulas. Este hecho nos da una 
idea de la importancia de la interacción de las bacterias con los virus para cualquier ecosistema terrestre (Forterre, 2013).

\section{$\S 5$. ¿SON ORGANISMOS LOS VIRUS?}

En general, todos los organismos son seres vivos, pero no todos los seres vivos son organismos.

Un organismo es una forma de vida compuesta de diferentes partes mutuamente interdependientes que mantienen diferentes procesos necesarios para la supervivencia.

Por lo tanto, para que exista un organismo debe haber una estructuración general del ser vivo en la que haya un alto grado de especialización funcional, de cooperación y de fuertes interacciones entre las partes (Pradeu, 2016).

Si se considera la virocélula, se podría hablar de un organismo en el que cada parte cumple su función, pero hay otra manera de considerar la posible inclusión de los virus dentro de la categoría de organismo. Este concepto es la simbiosis.

\subsection{La simbiosis como elemento interviniente en los procesos virales}

La simbiosis hace referencia a la asociación íntima entre seres de varias especies para beneficiarse mutuamente durante su desarrollo vital. Como vimos en otro apartado, los virus no siempre dañan al resto de seres vivos. En ocasiones los ayudan a su desarrollo o incluso lo hacen posible. También los protegen de otras infecciones o hacen que desaparezcan determinadas malformaciones o disfunciones del sistema inmunitario.

La simbiosis es un fenómeno omnipresente en la naturaleza. Se han estudiado dichos procesos en una amplia variedad de organismos, pero los virus a menudo se han dejado de lado en este tipo de investigaciones.

Pues bien, en opinión de Dupré y Guttinger (2016), los virus encajan bien en esta concepción integrada y colaborativa de los seres vivos que encon- 
tramos en la naturaleza. Los virus pueden ser útiles y colaboradores con sus huéspedes, formando con ellos sistemas y procesos biológicos integrados (Dupré y Guttinger, 2016). De hecho, ya hemos visto que los virus podrían ser considerados más bien como procesos que como sustancias o cosas independientes.

Sin embargo, no todos los autores están de acuerdo en considerar a las virocélulas como un organismo en sí mismo. Van Regenmortel (2016) rechaza esta idea por varios motivos. Para este autor, la infección vírica debería ser considerada siempre como una guerra entre el huésped y el virus. Los virus intentarán siempre desarrollar estrategias y mecanismos para defenderse de las respuestas inmunitarias que protegen a las células infectadas (Van Regenmortel, 2016).

Pero este punto de vista también tiene una limitación. A menudo atribuimos intenciones y objetivos a los organismos, y no estamos seguros de que podamos asumir este argumento al referirnos a los virus.

\subsection{Los virus como elementos que generan réplicas de sí mismos}

Todos los seres vivos que generan réplicas de sí mismos lo hacen en un continuo que se distribuye a lo largo de dos extremos: desde el egoísmo hasta la cooperación.

Los ciclos líticos son aquellos en los que la célula muere como consecuencia de la infección de un virus. En este extremo egoísta se situarían los llamados virus líticos. Este es el modo más extendido de replicación de los virus, y se da sobre todo en los virus más agresivos. Sin embargo, hay muchos otros virus moderados que ocupan una posición intermedia entre los extremos de cooperación y egoísmo, y en la que el huésped no muere y, por el contrario, obtiene ciertos beneficios tras la infección vírica.

De todas formas, la construcción de réplicas de manera egoísta no es exclusiva de los virus. Se da también en muchos otros seres vivos. Para Koonin y Starokadomskyy (2016), ningún sistema vivo puede evolucionar sin la presencia de parásitos. Más aún, los parásitos guían la evolución de la complejidad biológica en diferentes niveles. 
La historia de la vida en la Tierra es un proceso constante de coevolución entre parásitos y huéspedes. Todos los organismos son comunidades de diferentes replicadores que están evolucionando al mismo tiempo, interaccionado y formando comunidades. El uso de diferentes estrategias de replicación, desde las más egoístas a las más cooperativas, es una característica intrínseca de la evolución biológica (Koonin y Starokadomskyy, 2016).

Esta idea nos lleva a considerar a los virus como procesos que son clave para la evolución de la vida en la Tierra (Koonin y Dolja, 2013). Por lo tanto, según estos autores, los virus se caracterizan por:

- Parasitar todas las formas de vida celular.

- Representar la entidad biológica más genéticamente diferente y físicamente abundante en la Tierra.

- Utilizar todas las formas de replicación y expresión de genes posibles, en comparación con las células que suelen utilizar solamente una de ellas.

- Formar una especie de "mundo viral" en el que hay un pequeño conjunto de genes distintivos de los virus que codifican las funciones esenciales que realizan todos los virus conocidos.

- Evolucionar en paralelo con las células huésped mediante procesos extremadamente complejos que combinan una incesante competición con diferentes grados de cooperación.

En el apartado siguiente veremos una definición mucho más ajustada a lo que hemos expuesto en los apartados anteriores. No se trata de una definición generalista, pensada para la población, sino que fue propuesta en 1957 por Lwoff, con la intención de que los microbiólogos pudieran diferenciar qué es un virus y qué es un microorganismo.

Veremos que, aun así, deberemos seguir depurando esta definición para dar cabida a los descubrimientos que se han producido en los últimos años acerca de los virus. 


\section{§6. HaCIA UNA NUEVA DEFINICIÓN DE VIRUS}

El descubrimiento de una enorme variedad de virus gigantes en los primeros años del siglo Xxi ha llevado a cuestionar muchos de los conceptos que se habían ido asentando de manera progresiva a lo largo del siglo precedente.

Estos virus no solamente desconcertaron a los científicos por su tamaño y complejidad genética (mayor que las de muchas bacterias conocidas), sino porque, además (Fisher, Allen, Wilson y Suttle, 2010):

- No provocan daños en los humanos ni en los animales.

- No destruyen las cosechas.

- Muchos de ellos son atacados por virófagos, es decir, por virus que atacan o destruyen a otros virus.

- Algunos de ellos regulan la población de plancton unicelular a nivel mundial, del que depende la mitad de la producción de oxígeno y captación de carbono de nuestro planeta.

Como hemos visto en los apartados anteriores, los virus varían, como lo hacen otros seres vivos, a lo largo de un continuo entre parasitismo y cooperación. La distinción entre virus y célula se va haciendo cada vez más difusa, y lleva a los científicos a veces a proponer el concepto de virocélula, o hace difícil una clasificación de los virus en árboles de especies, como sucede con otros organismos.

En 1957, André Lwof propuso una definición de virus que en realidad consistía más bien en una lista para discriminar estas entidades de los microorganismos celulares. Para Lwof, los virus se caracterizaban porque (Lwoff, 1957):

- Mientras que las células contienen tanto ADN como ARN, los virus contienen solamente uno de los dos.

- En los microorganismos se reproducen todos sus componentes, mientras que en los virus se reproducen solamente sus ácidos nucleicos.

- En los microorganismos celulares cada individuo se reproduce mediante fisión binaria, mientas que en los virus no se da esta fisión. 
- Los virus no disponen de un sistema de enzimas para convertir la energía potencial contenida en los alimentos en la energía necesaria para la síntesis bioquímica.

- Los virus hacen uso de la maquinaria de traducción [ribosomas ${ }^{13}$ ] de las células huésped.

A continuación, veremos cómo estas características de los virus también han sido puestas en cuestión.

1. Los organismos celulares típicos contienen ADN y ARN, y los virus solamente contienen uno de ellos.

Esta afirmación es ambigua porque mezcla los conceptos de célula, virus y virión.

Si entendemos el virus como un proceso de replicación que se da dentro de la célula huésped, en determinados momentos de este ciclo de replicación no existe diferencia entre el virus y la célula (ambos forman una virocélula). Por lo tanto, este criterio no permitiría diferenciar a ambas entidades.

Por el contrario, si entendemos el virus como un virión, es decir, una entidad diferenciada de la célula, que se encuentra fuera de ella, tampoco sería cierta, porque se ha visto que algunos virus gigantes no solamente contienen ADN, sino también ARN mensajero (Raoult et al., 2004).

2. Todos los microorganismos se reproducen a partir de la suma integrada de sus constituyentes, mientras que los virus se producen a partir de su ácido nucleico.

Esta afirmación no es correcta, porque el ADN de los virus grandes y gigantes no es infeccioso si carece de una estructura concreta de proteínas.

Esta afirmación también es ambigua porque compara la célula con el virión (como entidad totalmente separada de la célula, y no como un proceso), mien-

\footnotetext{
${ }^{13}$ El ribosoma es un orgánulo de la célula que está compuesto de agua, ARN y proteínas, y cuya función es realizar la síntesis de proteínas.
} 
tras que el virus se entiende hoy en día como un proceso de replicación que tiene lugar en el interior de una célula huésped (Claverie y Abergel, 2016).

3. Durante el crecimiento de un microorganismo, la individualidad del conjunto se mantiene y termina con la fisión binaria. Esta fisión binaria no existe en los virus.

Si se considera al virus como una sustancia o ente independiente (virión), en lugar de como un proceso, esta afirmación puede parecer a primera vista correcta.

Sin embargo, sigue presentando varios problemas. El primero es que, como hemos visto, el virión se podría comparar a una semilla inactiva como, por ejemplo, la espora de una bacteria. Al igual que el virión, esta bacteria no se dividirá hasta que no se den las condiciones adecuadas.

Si consideramos el virus como un proceso de replicación intracelular, la afirmación seguirá siendo cierta en parte, porque la generación de nuevos virus no se hará por fisión binaria, sino mediante la generación de nuevas copias del virión.

Sin embargo, no todas las células se reproducen por fisión binaria. Hay bacterias que viven dentro de otras células, e incluso dentro de los núcleos de otras células, que parecen no disponer de este mecanismo de división celular binaria, sino que se dividen en múltiples células (Claverie y Abergel, 2016).

4. Los virus carecen de sistemas de enzimas que conviertan la energía potencial de los alimentos en la energía necesaria para la síntesis bioquímica.

Este criterio tampoco es válido porque muchas bacterias parásitas intracelulares tampoco son capaces de producir su propia energía (mediante $\mathrm{ATP}^{14}$ ) y utilizan la energía disponible en el citoplasma de la célula en la que se alojan.

${ }^{14} \mathrm{El}$ adenosín trifosfato (ATP) o trifosfato de adenosina es una molécula (nucleótido) fundamental para conseguir energía intracelular. Su fórmula es $\mathrm{C}_{10} \mathrm{H}_{16} \mathrm{~N}_{5} \mathrm{O}_{13} \mathrm{P}_{3}$. Se utiliza durante la respiración y fotorrespiración celular, y numerosos enzimas lo utilizan para realizar diferentes reacciones químicas. Una de las características fundamentales del ATP es su capacidad para almacenar energía que se libera de manera progresiva al llevarse a cabo las diferentes reacciones químicas dentro de la célula. 
Por el contrario, algunos virus codifican partes del sistema fotosintético proporcionando el mecanismo de adquisición de energía a su huésped tras la infección (Sharon et al., 2009).

5. Los virus usan los ribosomas de sus células huésped.

Esta afirmación es válida, pero algunas bacterias parásitas también los utilizan, en lugar de tener sus propios ribosomas (Claverie y Abergel, 2016).

\section{§7. ConCLusiones}

Todos los criterios anteriores nos demuestran que las diferencias que encontramos entre las células y los virus cada vez son menores, y resulta más complicado establecer una definición de qué es un virus (entendido como un proceso de replicación intracelular) que incluya solamente las características que hacen únicos a los virus.

Este intento fue realizado hace unos años por Claverie y Abergel (2016), por lo que presentamos a continuación la definición propuesta por estos autores:

Virus: cualquier entidad biológica en la que su genoma (moléculas de ácido nucleico): $a$ ) se replica mediante un sistema de macromoléculas que no codifica por completo y $b$ ) se dispersa usando una estructura metabólicamente inerte cuyo mantenimiento no requiere energía.

Como se puede comprobar, esta definición incluye cualquier tipo de genoma encapsulado dentro de cualquier tipo de partículas (con independencia del tamaño, la morfología o la composición bioquímica), por lo que no incluiría solamente los virus, sino que dentro de esta descripción se incluirían también otras moléculas de ácidos nucleicos, como los plásmidos ${ }^{15}$ (Claverie y

${ }^{15}$ Los plásmidos son moléculas de ADN que están fuera del único cromosoma bacteriano y que circulan por dentro de la célula bacteriana libremente, y se replican de forma autónoma y transmiten a otras células bacterianas al margen del ADN contenido en el cromosoma. En general, suelen tener un número pequeño de genes. 
Abergel, 2016). También Patrick Forterre considera que estas otras cadenas de información genética, como los plásmidos o los transposones ${ }^{16}$, deberían ser incluidas dentro de la amplia variedad de virus que existe sobre el planeta (Forterre, 2013).

Sin embargo, si queremos elaborar una definición que sea más específica de los virus (o procesos virales) y que distinga entre estos (que tienen una parte destacada de su ciclo reproductivo fuera de la célula) y los plásmidos y transposones (cuyo ciclo reproductivo se encuentra mayoritariamente dentro de esta), se podría proponer la siguiente definición:

Virus: Entidad biológica compuesta de proteínas y ácidos nucleicos, capaz de reproducirse en el seno de células vivas específicas, formando con ellas una unidad durante una parte de su ciclo reproductivo, y que una vez realizada la replicación se dispersa extracelularmente de manera inerte y sin consumo de energía.

Se trata de una definición que, sin duda, deberá ser ampliada o modificada en el futuro, cuando dispongamos de un conocimiento mayor de qué son los virus, pero que recoge todas las ideas y objeciones que hemos ido explicando a lo largo de este artículo.

\section{REFERENCIAS BIBLIOGRÁFICAS}

Ciencia Canaria - Gobierno de Canarias. (13 de abril de 2020). Los virus, ¿son seres vivos? Disponible en: <https:/www.cienciacanaria.es/secciones/ a-fondo/1096-los-virus-son-seres-vivos $>$.

Claverie, J., Abergel, C. (2016). Giant viruses: the difficult breaking of multiple epistemological barriers. Studies in History and Philosophy of Biological and Biomedical Sciences (59), 89-99.

${ }^{16}$ Los transposones son secuencias de ADN que pueden moverse libremente a diferentes partes del genoma de las células. A este fenómeno se le denomina transposición. Estos cambios pueden acabar provocando mutaciones en el material genético y cambios en la longitud total del ADN de una célula. Se les llama también "genes móviles" pero no tienen replicación autónoma.

SCIO. Revista de Filosofia, n. ${ }^{\circ}$ 19, Noviembre de 2020, 183-208, ISSN: 1887-9853 
Curtis, H., Barnes, N. (1993). Invitación a la Biología. Madrid: Editorial Médica Panamericana.

Dupré, J. (2012). Processes of life: Essays in the philosophy of biology. Oxford / New York: Oxford University Press.

Dupré, J., Guttinger, S. (2016). Viruses as living processes. Studies in History and Philosophy of Biological and Biomedical Sciences (59), 109-116.

Fisher, M. G., Allen, M. J., Wilson, W. H., Suttle, C. A. (2010). Giant virus with a remarkable complement of genes infects marine zooplankton. Proceedings National Academy Sciences U.S.A. 107(45), 19508-19513.

Forterre, P. (2013). The virocell concept and environmental microbiology. The ISME Journal 7, 233-236.

Forterre, P. (2016). To be or not to be alive: how recent discoveries challenge the traditional definitions of viruses and life. Studies in History and Philosophy of Biological and Biomedical Sciences 59, 100-108.

Kernbauer, E., Ding, Y., Cadwell, K. (2014). An enteric virus can replace the beneficial function of commensal bacteria. Nature 516(7529), 94-98.

Koonin, E. V., Starokadomskyy, P. (2016). Are viruses alive? The replicator paradigm sehds decisive light on an old but misguided question. Studies in History and Philosophy of Biological and Biomedical Sciences (59), 125-134.

Koonin, E., Dolja, V. (2013). A virocentric perspective on the evolution of life. Current Opinion in Virology 3(5), 546-557.

La Scola, B., Desnues, C., Pagnier, I., Robert, C., Barrassi, L., Fournous, G., ... Raoult, D. (2008). The virophage as a unique parasit of the giant mimivirus. Nature 455(7209), 100-104.

Lindell, D., Jaffe, J., Johnson, Z., Church, G., Chisholm, S. (2005). Photosynthesis genes in marine viruses yield proteins during host infection. Nature 438(7064), 86-89.

Luria, S., Darnell, J. (1977). Virología General. Barcelona: Ediciones Omega.

Lwoff, A. (1957). The concept of virus. Journal of General Microbiology 17, 239-253. 
Mallet, F., Bouton, O., Prudhomme, S., Cheynet, V., Oriol, G., Bonnaud, B., ... Mandrand, B. (2004). The endogenous retroviral locus ERVWE1 is a bona fide gene involved in hominoid placental physiology. Proceedings of the National Academy of Sciences of the United States of America 101(6), 1731-1736.

Morgan, G. (2016). What is a virus spices? Radical pluralism in viral taxonomy. Studies in History and Philosophy of Biological and Biomedical Sciences 59, 64-70.

National Human Genome Research Institute (13 de abril de 2020). https:// www.genome.gov. Disponible en: <https://www.genome.gov/geneticsglossary/Virus>.

O'Malley, M. (2016). The ecological virus. Studies in History and Philosophy of Biological and Biomedical Sciences 59, 71-79.

Pradeau, T., Kostyrka, G., Dupré, J. (2016). Understanding viruses: Philosophical investigations. Studies in History and Philosophy of Biological and Biomedical Sciences 59, 57-63.

Pradeu, T. (2016). Mutualistic viruses and the heteronomy of life. Studies in History and Philosophy of Biological and Biomedical Sciences 59, 80-88.

Raoult, D., Audic, S., Robert, C., Abergel, C., Renesto, P., Ogata, H., ... Claverie, J. (2004). The 1.2-megabase genome sequence of Mimivirus. Science 306(5700), 1344-1350.

Real Academia Española. (14 de abril de 2020). Diccionario de la Lengua Española. Disponible en: <https://dle.rae.es/virus $>$.

Sharon, I., Alperovitch, A., Rohwer, F., Haynes, M., Glaser, F., Atamna-Ismaeel, N., ... Béjà, O. (2009). Photosystem I gene cassettes are present in marine virus genomes. Nature 461(7261), 258-262.

Smith, K. (2012). Louis Pasteur, the father of immunology? Frontiers in Immunology 3(68), 1-10.

Van Regenmortel, M. (2016). The metaphor that viruses are living is alive and well, but it is no more than metaphor. Studies in History and Philosophy of Biological and Biomedical Sciences (59), 117-124. 
Webb, B., Strand, M., Dickey, S., Beck, M., Hilgarth, R., Barney, W., ... Witherell, R. (2006). Polyadnavirus genomes reflect their dual roles as mutualists and pathogens. Virology 374(1), 160-174.

Zimmer, C. (2015). A Planet of Viruses. Chicago: University of Chicago Press. 